\title{
Shadow Economy Worsens Income distribution
}

\author{
Ioannis Gasteratos ${ }^{1}$, Michael Karamalis ${ }^{2}$. Andreas Koutoupis ${ }^{3}$
}

\begin{abstract}
:
Shadow economy has many repercussions affecting most sectors of the economy. Our research question is how shadow economy affects income distribution. The contribution of the present paper is that if is found that shadow economy worsens income distribution.

Our sample includes the following countries Austria, Belgium, Cyprus, Denmark, Finland, France, Germany, Greece, Ireland, Italy, Netherlands, Portugal, Spain, Sweden and UK. It becomes evident that, international accounting standards and international standards of auditing should be adopted by EU members to eliminate shadow economy, and thus promote not only economic growth but also political stability.
\end{abstract}

The structure of this paper has as follows. Literature review will be presented in sectorl. In sector 2 the econometric model will be analyzed and finally conclusions will be discussed in sector 3 .

Keywords: shadow economy; tax evasion; economic growth; income distribution; panel data analysis

JEL classifications: E26; E25; O17; C33

\footnotetext{
${ }^{1}$ Phd, University of the Aegean, Greece, giannigaster@yahoo.gr

${ }^{2}$ Phd, University of the Aegean, Greece, michael.karamalis@gmail.com

${ }^{3}$ Phd, CMIIA,CIA,CICA,CCSA,CRMA,CCS, anreas.koutopis@mazars.gr
} 


\section{Introduction}

The main reason of shadow economy is tax evasion. An extensive literature is found in (Schneider and Enste, 2000). Shadow economy, which is a world-wide problem, has many forms. One of them and very common is earning management, that is used by companies to pay less taxes (Guenther, 1994).

This is done mainly by large companies ${ }^{4}$. Earnings management has been examined by many economists: DeAngelo (1986), Jones (1991), Cahan (1992) and showed a considerable increase during the period 1997-2002 (Cohen et al., 2004). The rapid technological progress as well as the fast change in capital markets are two important reasons that made accounting system very complicated. According to Allingham and Sandmo (1972) and Srinivasan (1973) the international auditing standards are one important determinant factor to reduce tax evasion. Consequently, auditing is required to guarantee that company's income statements become trustworthy. Further, Kerr (2015) asserts that countries, where companies have greater levels of transparency, experience lower levels of tax avoidance. Further, an increased transparency gives better, trustworthy and reliable information to the would-be investors. Hence, international investments will be increased ending up with economic growth (Georgiou, 2013a; Thalassinos et al., 2012a; 2012b).

\section{Shadow Economy's Impacts}

\subsection{Trying to restrict shadow economy is difficult}

According to (Hanlon et al., 2008) the increase in book-tax conformity resulted in a decrease in the informativeness of the firms' accounting earnings. To our knowledge this is a unique result in that it is a case of a tax law change that has an adverse consequence on the informativeness of accounting earnings. Besides, based on (Georgiou, 2013b) restricting shadow economy has some costly side effects.

\subsection{Shadow economy's impact on Share Prices}

According to Weber (2006) analysts' systematic errors proxy for similar errors made by investors concerning book-tax differences for future earnings lead to mispricing. According to (Kim et al., 2011) Using a large sample of U.S. firms for the period 1995-2008, we provide strong and robust evidence that corporate tax avoidance is positively associated with firm-specific stock price crash risk. According to Georgiou (2013) shadow economy pushes up share prices. There are countries where there are firms not listed in the stock market, in which tax evasion takes place. In

\footnotetext{
4 It is made mainly by large companies that have well organized accounting department. Hence, large companies (compared to the small and medium firms) are in a position to show a better picture in order to attract investors in the future. Hence, there is a distortion in market competition.
} 
these countries the method of earnings management happens many times. Further, earnings management takes place in order to show that the company has met its targets so as to increase its share price (Bartov et al., 2002). It should be also noted that firms aim to remain competitive and to meet their obligations to third parties (Cormier and Magnan, 1996) to avoid bankruptcy. Hence, they sometimes hide various costs, to avoid an increase in the interest rates of their loans ${ }^{5}$.

\subsection{Shadow economy impact on Inflation and Taxation}

According to (Mazhar and Méon, 2012) in a sample of developed and developing countries during the period 1999-2007, a positive relation is found between inflation and the size of the shadow economy. Further, tax burden tends to increase shadow economy (Schneider, 2012).

\subsection{Shadow economy impact on Competition}

According to the study of (Armbrecht and Carlback, 2011) after making a survey of 535 restaurants in Sweden it is found that it is very difficult not only to survive as a law-abiding firm, but also that the unfair competition (due to shadow economy) affects the whole sector's progress and development. In other words, shadow economy is an obstacle to the competition. Firms in a globalized environment resorted to earnings management in order to attract would-be investors ${ }^{6}$ (Vanasco, 1998).

\subsection{Corruption and shadow economy}

According to (Dreher and Schneider, 2010) there is not any significant relationship between corruption and the size of the shadow economy. However, in low income countries corruption and the shadow economy are complements and there is no protection of investors Wang (2014).

\subsection{Developed Economies vs Rest of the World}

According to (Fleming et al., 2000; Schneider and Enste, 2000) shadow economy is larger in transition and developing countries Wang (2014). Particularly, within EU southern EU States have higher levels of shadow economy ${ }^{7}$.

\footnotetext{
${ }^{5}$ This lack of transparency distorts fair competition and is an obstacle for economic growth (Georgiou, 2013a).

${ }^{6}$ This lack of transparency distorts fair competition and is an obstacle for economic growth (Georgiou, 2013a).

${ }^{7}$ See, for example, Contini, B. "The Second Economy of Italy", in Vito Tanzi, ed., The Underground Economy in the United States and Abroad (Lexington, MA: D.C. Heath and Company, 1982) pp.199-208.
} 
2.7 The role of institutions, Democracy and State governance to fight shadow economy

An improvement in the institutional quality reduce shadow economy and corruption (Dreher et al., 2009; Torgler and Schneider, 2007). Similarly, according to Torgler et al., (2010) local autonomy and federal system tend to reduce shadow economy. Further, direct democracy and democratic institutions cause a decrease of the size of shadow economy (Teobaldelli and Schneider, 2012). Besides, world history has shown that countries, having robust accounting systems and high levels of transparency, enjoy economic growth and political stability (Georgiou et al., 2015; Bekiaris et al., 2011).

\subsection{Shadow economy on entrepreneurship}

According to (Estrin and Mickiewicz, 2012) shadow economy hinders entrepreneurial entry. Further, shadow economy is an obstacle to entrepreneurial activity (Georgiou, 2013a).

\subsection{Shadow Economy on Unemployment}

According to the work of Boeri and Garibaldi, (2002) an effort by the official state to reduce shadow economy will increase unemployment. This finding agrees with the study of Georgiou, (2013b) indicating that shadow economy is hard to fight without any cost of side effects.

\subsection{Shadow Economy's Impact on Income Distribution}

Since, tax avoidance reduces the total tax revenues, then "tax burden" on "honest" tax payers are expected to go up ${ }^{8}$ in order to cover the tax revenue generated gap. Consequently, this tax burden will be at the cost of income distribution (Georgiou, 2013c; Alm, 2014). In other words, only "honest" tax payers will pay this increased tax burden, which will cause a further reduction in their disposable income and finally income distribution will be worse than before.

\subsection{Conclusions of this section}

After the afore mentioned it becomes clear that shadow economy can affect economy in various ways and in many sectors. Tax evasion causes lower tax revenues and ultimately the higher effective tax rate (to cover the tax revenue gap) falls on the shoulders of honest tax payers. Hence, it is expected a priori that shadow economy will affect income distribution. Our research question is then "how shadow economy affects income distribution".

\footnotetext{
${ }^{8}$ In other words, effective tax rate will increase in order to compensate for the reduction of tax revenues, which is created by tax evasion.
} 


\section{Income Distribution Estimation}

Gini statistic is worldwide known as an indicator of income distribution ${ }^{9}$. Following the definition of $\mathrm{OECD}^{10}$ index GINI ${ }^{11}$ measures the degree of income distribution (and in some cases the consumption expenditure) among individuals or households. Its value ranges from 0 to 1 (or as a percentage from 0 to 100). When its value equals to 0 , then this is the ideal situation in which income distribution is completely equal among individuals. On the contrary, the value 1 indicates the extreme case in which income distribution is totally unequal. Consequently, the higher the value of Gini the worse income distribution is. However, there are intermediate cases. In fact, according to Luebker (2010) an index Gini around 0,20 indicates a low level of unequal income distribution. Values around 0,25 show a moderate level of unequal income distribution, while values around 0,35 indicate a highly unequal distribution of income and finally for values beyond 0,50 then there is an extremely unequal income. In the graph 1 one can see the different levels of income distribution inequality between USA and many countries of EU.

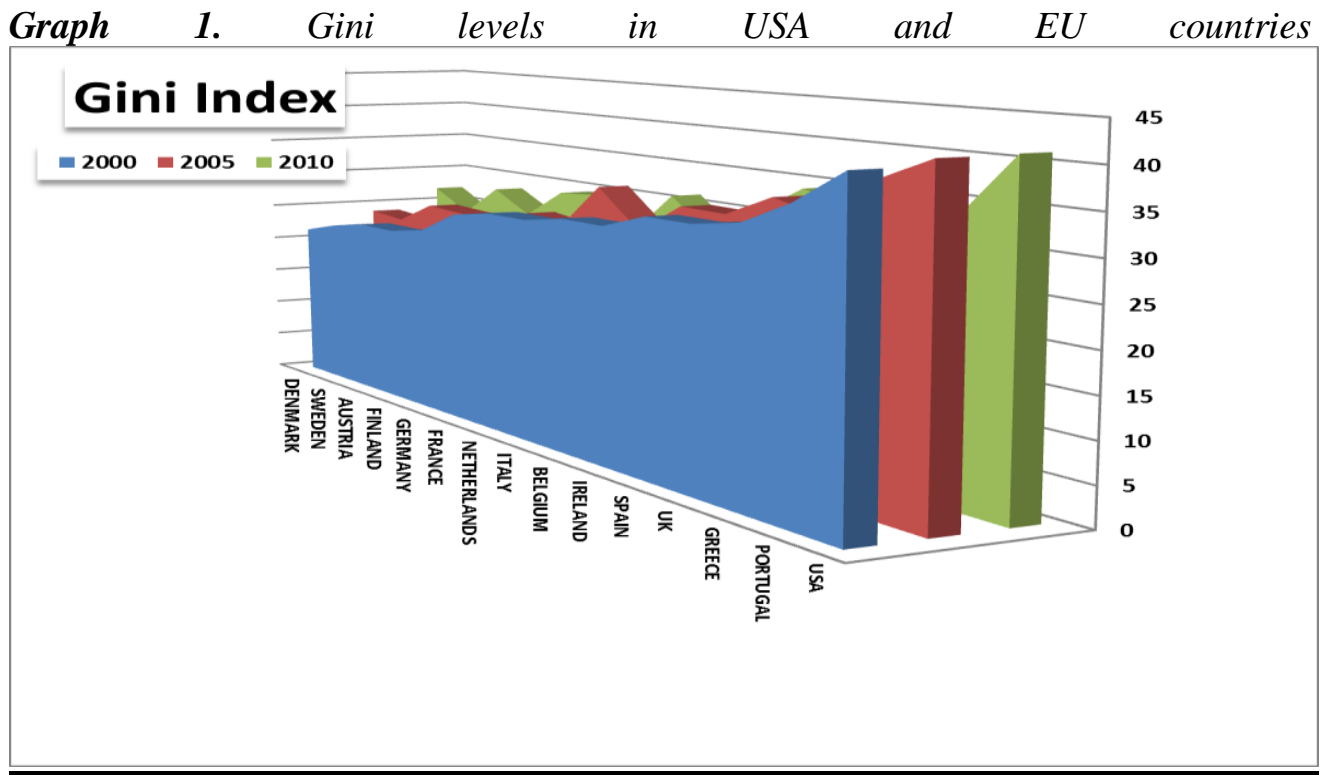

Source: Eurostat, OECD

One can observe in the graph 1 that income distribution in the USA is during period 2000-2010 worse than many European countries. More specifically, between the selected European countries the worst income distribution appears in Portugal, and the remaining countries have better income distribution improving according to the

\footnotetext{
${ }^{9}$ To be comprehensive, there are many ways to estimate income distribution (Stewart et al., 2005). However, Gini index is the one world-wide used.

${ }^{10}$ http://stats.oecd.org/glossary/detail.asp? ID $=4842$

${ }^{11}$ It took the name after the famous Italian Statistician Corrado Gini (1884-1965).
} 
following order: Greece, UK, Spain, Ireland, Belgium, Italy, Netherlands, France, Germany, Finland, Austria, Sweden and Denmark.

It should be noted that recent world economic crisis had as a repercussion the worsening of income distribution (Özlem Onaran, 2009). Besides, the German policy concerning the budgetary discipline was strongly criticized by IMF (Schrörsand Pache, 2009). It is well known that the various austerity measures resulted in a consumption decline ${ }^{12}$. Furthermore, firms faced losses ${ }^{13}$ and unemployment has risen. Hence, austerity measures worsened income distribution (Theodoropoulou and Watt, 2011; Georgiou, 2012).

\section{Income distribution determinants}

However, it should be mentioned that shadow economy is not the only income distribution determinant. In fact, entrepreneurship, by creating jobs, tends to reduce income inequality (Georgiou, 2009), because entrepreneurship reduces unemployment ${ }^{14}$. Further, education spending improves income distribution, for educated people find jobs easily (Georgiou, 2010b) ${ }^{15}$. Besides, globalization can improve income distribution (IMF, 2007); (Georgiou, 2010) ${ }^{16}$. Inflation is also a serious factor that worsens income distribution (Jäntti and Jerkins, 2001; Georgiou, 2010a; Oberdabernig, 2013). Furthermore, economic crisis and the imposed austerity measures tend to worsen income distribution (Georgiou, 2012c; Theodoropoulou and Watt, 2011; Özlem Onaran, 2009). One should not forget the contribution of the trade unions towards the improvement of income distribution (Checchi and GarciaPeñalosa, 2005; Georgiou, 2012a $)^{17}$. Finally, it is claimed that decentralization (Georgiou, 2012b) as well as Federal system and political stability (Georgiou, 2015) help to improve income distribution.

\section{Our Research Hypothesis}

Based on the afore-mentioned our research hypothesis is: Ho: "Shadow economy has no impact on income distribution"

\subsection{Data}

\footnotetext{
${ }^{12}$ Mainly in Greece (Georgiou et al.,2015).

${ }^{13}$ This can be explained by the consumption-led growth theory (Saito, 2007).

${ }_{14}^{14}$ In fact a reduction in unemployment improves income distribution (Jäntti and Jerkins, 2001).

${ }^{15}$ Again in this case unemployment is reduced.

${ }^{16}$ According to (Atif et al., 2012) the impact of globalisation on income distribution differs among countries.

${ }^{17}$ It should be mentioned that trade unions are also responsible for the creation of "wage rigidities" (Toichiro Asada et al., 2003), that might cause unemployment. This topic however goes beyond the limits of the present paper.
} 
Variable (Gini) is taken from Eurostat. Shadow Economy data (sh_ec) as a percentage of official $\mathrm{GDP}^{18}$ are taken from (Schneider et al., 2010; Schneider, 2013). The period covered is 2000-2013 annually, and our data refer to Austria (2000-2013), Belgium (2000-2013), Cyprus (2004-2013), Denmark (2000-2013), Finland (2000-2013), France (2003-2013), Germany (2000-2013), Greece (20002013), Ireland (2000-2012), Italy (2000-2013), Netherlands (2000-2013), Portugal (2000-2013), Spain (2000-2013), Sweden (2000-2013) and UK (2000-2013).

\subsection{The Regression}

The econometric model is shown by equation (1).

$\boldsymbol{G i n i}_{i t}=c_{0}+c_{1}$ sh_ec $_{i t}+$ error $_{i t}(1)$

This model is estimated by Panel EGLS (Cross section weights) ${ }^{19}$, at a significance level $\alpha=0,01$.

\subsection{Results}

Table 1. Regression Results in Brief

\begin{tabular}{|l|l|l|}
\hline Variable & Coefficient & P-value \\
\hline Constant & 24,870 & 0,0000 \\
\hline sh_ec & 0,266 & 0,0021 \\
\hline $\mathrm{R}^{2}$ & 0,160 & $\cdots$ \\
\hline Adjusted $\mathrm{R}^{2}$ & 0,156 & $\cdots$ \\
\hline S.E. of regression & 3,476 & $\ldots$ \\
\hline F-statistic & 38,217 & 0,0000 \\
\hline Durbin-Watson stat & 1,970 & $\cdots$ \\
\hline
\end{tabular}

\subsection{Comments}

With a sample size equal to 202 , (at $1 \%) \mathrm{d}_{\mathrm{U}}=1,6850<\mathrm{DW}=1,970029$. Hence, there is no serial correlation in this model. All coefficients (including the constant term) are statistically significant, and positive, for all $p$-values $<\alpha$. Finally, $p$-value of $(F$ statistic $)<\alpha$. This indicates that the vector of explanatory variable does explain the variations of the vector of dependent variable (Pindyck and Rubinfeld, 1998). The determination coefficient indicates that $16 \%$ of the variations in income distribution are explained by the present model.

\footnotetext{
${ }^{18}$ Without allowing for the shadow economy part.

${ }^{19}$ For a detailed econometric analysis see (Halkos and Georgiou, 2005).
} 
Graph 2. The Distribution of Residuals

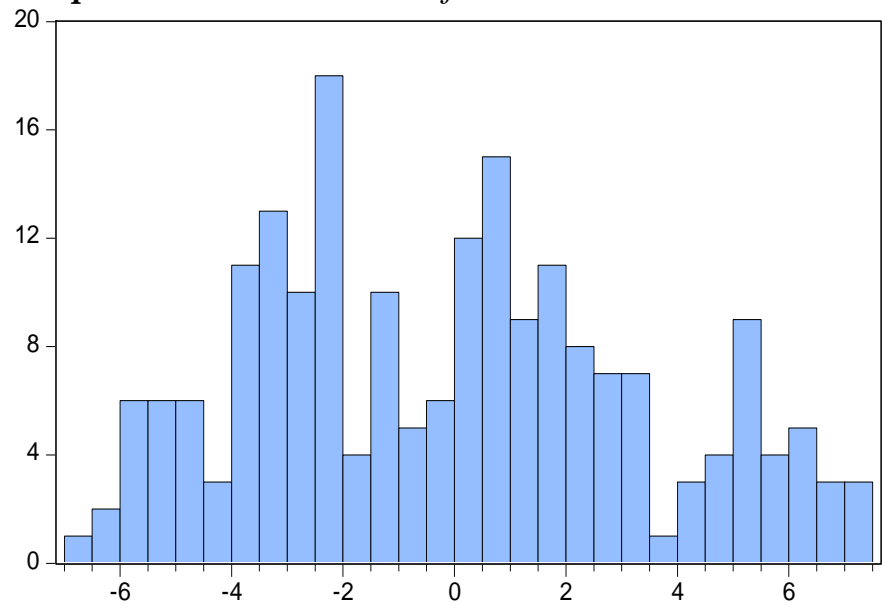

Series: Standardized Residuals

Sample 1202

Observations 202

Mean $\quad-0.096584$

Median $\quad-0.041384$

Maximum $\quad 7.303453$

Minimum $\quad-6.840950$

Std. Dev. $\quad 3.466024$

Skewness $\quad 0.252625$

Kurtosis $\quad 2.210404$

Jarque-Bera 7.396066

Probability $\quad 0.024772$

Jarque-Bera $(J B)$ statistic is estimated by the following equation (2):

$J B=n *\left[\frac{S^{2}}{6}+\frac{(K-3)^{2}}{24}\right]$

where: $S$ (skewness), $K$ (kurtosis) and $n$ (the sample size). JB statistic follows a chisquare distribution ${ }^{20}$, and the null hypothesis Ho is: "the residuals of the regression are normally distributed" (Vogelvang, 2005).

\subsection{Robustness of the Model}

The following tests aim to check if our model is robust.

Table 2. Unit Root Test ${ }^{21}$ for [gini]

\begin{tabular}{|l|l|c|}
\hline Method & Statistic & P-value \\
\hline Im, Pesaran and Shin W-stat & $-4,333$ & 0,0000 \\
\hline ADF - Fisher Chi-square & 67,433 & 0,0000 \\
\hline PP - Fisher Chi-square & 169,814 & 0,0000 \\
\hline
\end{tabular}

\subsection{Comments}

Variable gini is stationary ${ }^{22}$ since all $p$-values $<\alpha$.

\footnotetext{
${ }^{20}$ See (Pindyck and Rubinfeld, 1998).

${ }^{21}$ A similar unit root test can be found in (Georgiou et al.,2015)

${ }^{22}$ All variables must be stationary in order to be able to estimate the regression.
} 
Table 3. Unit Root Test for [sh_ec]

\begin{tabular}{|l|l|l|}
\hline Method & Statistic & P-value \\
\hline Im, Pesaran and Shin W-stat & $-3,040$ & 0,0012 \\
\hline ADF - Fisher Chi-square & 53,986 & 0,0022 \\
\hline PP - Fisher Chi-square & 176,691 & 0,0000 \\
\hline
\end{tabular}

Variable sh_ec is stationary ${ }^{23}$ since all p-values $<\alpha$.

Table 4. Diagnostic Tests of Model Robustness ${ }^{24}$

\begin{tabular}{|l|l|l|}
\hline TESTS & Model & $\begin{array}{l}\text { Critical values } \\
(\boldsymbol{\alpha}=\mathbf{0 , 0 1})\end{array}$ \\
\hline Heteroskedasticity $^{(*)}$ & 0,000 & 11,350 \\
\hline RESET $^{(* *)}$ & 0,014 & 6,340 \\
\hline Normality $^{(* *)}$ & 7,397 & 9,210 \\
\hline
\end{tabular}

Notes:

(*) Regression of the log of squared residuals on X (a Harvey test)

(**) Regression of residuals on $\hat{\mathrm{Y}}^{2}$

${ }^{(* * *)}$ Normality test (Jarque Bera) (see Vogelvang, 2005)

The robustness tests (see Table 4) are made in order to check whether the basic assumptions for the construction of the above model are met. To begin with, the assumption of homoskedasticity is fulfilled since, according to the above Harvey test, the statistic is less than the critical value 11,350. Besides, the specification of this model is correct, since the RESET statistic is less than the critical value 6,340 . Further, the distribution of the regression residuals in this model is normal, since Jarque Bera statistic is less than the critical value 9,210. Finally, there is no serial correlation, since at $\alpha=1 \%, \mathrm{~d}_{\mathrm{U}}=1,6850<\mathrm{DW}=1,970$. Needless to mention that all variables [Gini] and [sh_ec] are stationary, since Im, Pesaran and Shin W-stat, ADF - Fisher Chi-square, and PP - Fisher Chi-square have all $p$-values $<\alpha$. Consequently, the afore-mentioned model is robust.

\section{Concluding}

\subsection{Findings and discussion}

According to this model at a level of significance $1 \%$ the afore mentioned research hypothesis is not accepted. More specifically, shadow economy, which is created by tax evaders, has a positive impact on Gini coefficient. In economic jargon this means that as shadow economy grows then income distribution worsens. This finding is in agreement with Georgiou (2013c), where a different econometric model was used.

${ }^{23}$ All variables must be stationary in order to be able to estimate the regression.

${ }^{24}$ These robustness tests are based on Halkos (2003). 
This impact on Gini is not fair, and in the long run it might be unfortunately a "motive" for the today's "legal and honest taxpayers" to turn into "tax evaders" in the future. If this takes place, then the size of shadow economy will increase even further, and the created lack of transparency will hinder entrepreneurs to invest and create economic growth. Thus, shadow economy will be an obstacle to economic growth.

Apart from that consequence, according to this model income distribution will worsen even further, thus poverty will tend to increase. This situation will create some social problems in the long run. According to the empirical analysis of Georgiou (2014) a poverty increase in EU will cause a decrease in confidence on the Institutions of the EU and the general entity of EU. Policy makers should take this seriously.

Consequently, international accounting standards and international standards of auditing should be adopted by EU members in order to eliminate tax avoidance, which is a great segment of shadow economy, and thus promote not only economic growth but also political stability.

\subsection{Further research}

This model refers on the impact of total shadow economy on income distribution. The afore mentioned model could be enhanced by taking into account additional income distribution determinant factors, such as: entrepreneurship (Georgiou, 2009), education spending (Georgiou, 2010b), austerity measures (Georgiou, 2012c); (Theodoropoulou and Watt, 2011); (Özlem Onaran, 2009) and finally economic crisis, which hits mainly southern EU.

\section{References}

Allingham, M. G., \& Sandmo, A. 1972. Income tax evasion: A theoretical analysis. Journal of Public Economics, 1(3-4), 323-338.

Alm, J. 2014. Tax evasion, labor market effects, and income distribution. IZA World of Labor. http://wol.iza.org/articles/tax-evasion-labor-market-effects-and-incomedistribution.pdf

Armbrecht, J. \& Carlback, M. 2011. The Shadow Economy: Its Effects on the Competition in the Swedish Restaurant Industry. Tourism in an Era of Uncertainty Rhodes Island, Greece 27-30.

Atif, S.M., Srivastav, M., Sauytbekova, M., \& Arachchige, U.K. 2012. Globalization and Income Inequality: A Panel Data Analysis of 68 Countries. https://mpra.ub.unimuenchen.de/42385/1/MPRA_paper_42385.pdf

Bartov, E., Givoly, D. \& Hayn, C. 2002. The rewards to meeting or beating earnings expectations. Journal of Accounting and Economics, 33, 173-204.

Bekiaris, M. and Sgouros, T. and Tasios, S. 2011. Financial Reporting Quality in Greece: A Case Study of Auditor's Qualifications. University of the Aegean, Conference for the 25 Years of the Business Administration Department, SSRN: 
http://ssrn.com/abstract=2447613

Boeri, T. \& Garibaldi, P. 2002. Shadow activity and unemployment in a depressed labour market.https://www.researchgate.net/profile/Pietro_Garibaldi/publication/4753874_ Shadow_Activity_and_Unemployment_in_a_Depressed_Labor_Market/links/54734 f4f0cf2d67fc036235e.pdf

Cahan, S.F. 1992. The Effect of Antitrust Investigations on Discretionary Accruals. A Refined Test of the Political Cost Hypothesis. The Accounting Review 67, 77-95.

Checchi, D. and Garcia-Peñalosa, C. 2005. Labour Market Institutions and the Personal Distribution of Income in the OECD. Center for Economic Studies \& Ifo Institute for Economic Research CESifo Working Paper No. 1608 and Institute for the Study of Labor IZA, IZA Discussion Paper No. 1681.

Cohen, D.A., Dey, A. and Lys, T.Z. 2004. Trends in earnings management and informativeness of earnings announcements in the Pre- and Post-Sarbanes Oxley Periods. Working paper, Northwestern University, November 2004.

Contini, B. 1982. The Second Economy of Italy. In Vito Tanzi, ed., The Underground Economy in the United States and Abroad (Lexington, MA: D.C. Heath and Company), 199-208.

Cormier, D. Magnan, M. \& Morard, B. 2000. The contractual and value relevance of reported earnings in a dividend-focused environment. European Accounting Review, 9(3), 387-417.

DeAngelo, L. 1986. Accounting Numbers as Market Valuation Substitutes: A Study of Management Buyouts of Public Stockholders. The Accounting Review, 61, 400420.

Dreher, A. \& Schneider, F. 2010. Corruption and the shadow economy: An empirical analysis. Public Choice, 144(1-2), 215-238.

Dreher, A. Kotsogiannis, C. \& McCorriston, S. 2009. How do institutions affect corruption and the shadow economy? International Tax and Public Finance, 16(6), 773-796.

Estrin, S. \& Mickiewicz, T. 2012. Shadow economy and entrepreneurial entry. Review of Development Economics, 16(4), 559-578.

Fleming, M.H. Roman, J. \& Farrell, G. 2000. The shadow economy. Journal of International Affairs, 387-409.

Georgiou, M. and Kyriazis, N. and Economou, E.M.L. 2015. Democracy, Political Stability and Economic Performance. A Panel Data Analysis. Journal of Risk \& Control, 2(1) 1-18.

Georgiou, M.N. 2009. Entrepreneurship Reduces Income Inequality. Available at SSRN: http://ssrn.com/abstract=1485704 or http://dx.doi.org/10.2139/ssrn.1485704

Georgiou, M.N. 2010. Globalization and Income Distribution Within Countries: An Empirical Analysis with Panel Data in Western World. Available at SSRN: http://ssrn.com/abstract=1714426 or http://dx.doi.org/10.2139/ssrn.1714426

Georgiou, M.N. 2010a. Income Distribution and Inflation: An Empirical Analysis for Western Europe (1995-2006). Available at SSRN: http://ssrn.com/abstract=1542696 or http://dx.doi.org/10.2139/ssrn.1542696

Georgiou, M.N. 2010b. Education Spending and Income Inequality - An Empirical Analysis for Western Europe (1995-2006). Available at SSRN: http://ssrn.com/abstract=1557325 or http://dx.doi.org/10.2139/ssrn.1557325

Georgiou, M.N. 2012. Austerity Measures Impact on Entrepreneurship, Employment as Well as Income Distribution: A Panel Data Analysis in EU. Available at SSRN: http://ssrn.com/abstract=2186829 or http://dx.doi.org/10.2139/ssrn.2186829

Georgiou, M.N. 2012a. Trade Union Power and Income Distribution: A Panel Data Analysis 
for Western Europe (1999-2008). Available at SSRN:

http://ssrn.com/abstract=2181429 or http://dx.doi.org/10.2139/ssrn.2181429

Georgiou, M.N. 2012b. Decentralization and Income Distribution: A Panel Data Analysis for

EU. Available at SSRN: http://ssrn.com/abstract=2187063 or

http://dx.doi.org/10.2139/ssrn.2187063

Georgiou, M.N. 2012c. Austerity Measures Impact on Entrepreneurship, Employment as Well as Income Distribution: A Panel Data Analysis in EU. Available at SSRN: http://ssrn.com/abstract=2186829 or http://dx.doi.org/10.2139/ssrn.2186829

Georgiou, M.N. 2013. The Impact of Shadow Economy on the Stock Market Volatility. A Worldwide Panel Data Analysis. Available at SSRN:

http://ssrn.com/abstract=2354369 or http://dx.doi.org/10.2139/ssrn.2354369

Georgiou, M.N. 2013a. Shadow Economy Hinders Entrepreneurship. Available at SSRN: http://ssrn.com/abstract=2358005 or http://dx.doi.org/10.2139/ssrn.2358005

Georgiou, M.N. 2013b. Restricting Shadow Economy versus Macroeconomic Impacts. A Panel Data Analysis in EU, Japan, USA. Available at SSRN: http://ssrn.com/abstract=2369402 or http://dx.doi.org/10.2139/ssrn.2369402

Georgiou, M.N. 2013c. Income Distribution and Shadow Economy. A Worldwide Panel Data Analysis. Available at SSRN: http://ssrn.com/abstract=2357401 or http://dx.doi.org/10.2139/ssrn.2357401

Georgiou, M.N. 2014. Poverty and Confidence in EU: A Note. Available at SSRN: http://ssrn.com/abstract=2457420 or http://dx.doi.org/10.2139/ssrn.2457420

Georgiou, M.N. 2015. Federation, Income Distribution and Political Stability. Available at SSRN: http://ssrn.com/abstract=2709431 or http://dx.doi.org/10.2139/ssrn.2709431

Guenther, D.A. 1994. Earnings Management in Response to Corporate Tax Rate Changes: Evidence from the 1986 Tax Reform Act. The Accounting Review, 69(1), 230-243.

Halkos, G.E. 2003. Environmental Kuznets Curve for Sulphur: Evidence Using GMM Estimation and Random Coefficient Panel Data Models. Environment and Development Economics, 8, 581-601.

Halkos, G.E. and Georgiou, M.N. 2005. Bank Sales, Spread and Profitability: An Empirical Analysis. Applied Financial Economics Letters.

Hanlon, M. Maydew, E.L. \& Shevlin, T. 2008. An unintended consequence of book-tax conformity: A loss of earnings informativeness. Journal of Accounting and Economics, 46(2), 294-311.

IMF. 2007. Globalization and Inequality; Chapter 4. World Economic Outlook, October. Available at: http://www.imf.org/external/pubs/ft/weo/2007/02/pdf/c4.pdf

Jäntti, M. and Jenkins, S.P. 2001. Examining the Impact of Macro-Economic Conditions on Income Inequality. IZA Discussion Paper No. 364.

Jones, J. 1991. Earnings Management During Import Relief Investigations. Journal of Accounting Research 29, 193-228.

Kerr, J.N. 2015. Transparency, Information Shocks, and Tax Avoidance. Available at SSRN: http://ssrn.com/abstract=2761140 or http://dx.doi.org/10.2139/ssrn. 2761140

Kim, J.B. Li, Y. \& Zhang, L. 2011. Corporate tax avoidance and stock price crash risk: Firmlevel analysis. Journal of Financial Economics, 100(3), 639-662.

Luebker, M. 2010. Inequality, income shares and poverty: The practical meaning of Gini coefficients. Travail Policy Brief No 3, ILO.

Mazhar, U. \& Méon, P.G. 2012. Taxing the unobservable: The impact of the shadow economy on inflation and taxation. Working Papers, CEB, 12.

Oberdabernig, D.A. 2013. Revisiting the effects of IMF programs on poverty and inequality. World Development, 46, 113-142. 
Özlem, Onaran 2009. From the Crisis of Distribution to the Distribution of the Costs of the Crisis: What Can We Learn from Previous Crises about the Effects of the Financial Crisis on Labor Share? Political Economy Research Institute, Working Paper No 195. University of Massachusetts Amherst.

Pindyck, R.S. and Rubinfeld, D.L. 1998. Econometric Models and Econometric Forecasts, McGraw-Hill.

Saito, T. 2007. Economy Must Shift to Consumption-Led Growth. Economic Forecast for FY 2007-2008. Economic Research Group, NLI Research. Available from: http://www.nli-research.co.jp/english/economics/2007/eco070803.pdf

Schneider, F. \& Enste, D. 2000. Shadow Economies around the World Size, Causes, and Consequences. http://faculty.nps.edu/relooney/Schneider.pdf

Schneider, F. 2012. The shadow economy and work in the shadow: What do we (not) know? https://www.econstor.eu/bitstream/10419/58986/1/715723030.pdf

Schneider, F. 2013. Size and Development of the Shadow Economy of 31 European and 5 other OECD Countries from 2003 to 2013: A Further Decline. Johannes Kepler Universität, Linz, 5-7.

Schneider, F. Buehn, A. and Montenegro, E.C. 2010. New Estimates for the Shadow Economies all over the World. International Economic Journal 24(4), 443-461.

Srinivasan, T.N. 1973. Tax evasion: a model. Journal of Public Economics, 2(4), 339-346.

Stewart, F. Brown, G. and Mancini, L. 2005. Why Horizontal Inequalities Matter: Some Implications for Measurement. CRISE Working Paper No. 19.

Teobaldelli, D. \& Schneider, F. 2012. Beyond the veil of ignorance: The influence of direct democracy on the shadow economy. CESifo Working Paper MO3749, University of Munich, Munich.

Thalassinos, I.E., Ugurlu, E. and Muratoglu, Y. 2012a. Income Inequality and Inflation in the EU. European Research Studies Journal, 15(1), 127-140.

Thalassinos, I.E., Hanias, P.M. and Curtis, G.P. 2012b. Time series prediction with neural networks for the Athens Stock Exchange indicator. European Research Studies Journal, 15(2), 23-31.

Theodoropoulou, S. and Watt, A. 2011. Withdrawal Symptoms: An Assessment of the Austerity Packages in Europe. ETUI Working Paper 2011.02. Available at SSRN: http://ssrn.com/abstract=2221838 or http://dx.doi.org/10.2139/ssrn.2221838

Toichiro Asada, Carl Chiarella, Peter Flaschel, Reiner Franke, 2003. Interacting two country business fluctuations: "Euroland and the USA. European Commission Working Papers and Studies.

Torgler, B. \& Schneider, F. 2007. Shadow economy, tax morale, governance and institutional quality: a panel analysis. https://www.econstor.eu/bitstream/10419/25968/1/538033703.PDF

Torgler, B. Schneider, F. \& Schaltegger, C.A. 2010. Local autonomy, tax morale, and the shadow economy. Public Choice, 144(1-2), 293-321.

Vanasco, R.R. 1998. Fraud auditing. Managerial Auditing Journal, 13(1), 4-71.

Vogelvang, B. 2005. Econometrics, Theory and Applications with E-views. Prentice Hall.

Wang, X. 2014. New evidence on real earnings management: An international investigation. A thesis submitted to Auckland University of Technology.

Weber, D. 2006. Book-tax differences, analysts' forecast errors, and stock returns. Working paper, University of Connecticut. http://citeseerx.ist.psu.edu/viewdoc/download?doi=10.1.1.476.1231\&rep=rep1\&typ $\mathrm{e}=\mathrm{pdf}$ 